\title{
A POLÍTICA DA V0Z
}

\author{
MLaden Dolar \\ University of Ljubljana
}

A dimensão política da voz, sua implicação profunda na constituição da política, talvez seja mais bem abordada na origem, no começo mesmo da filosofia política, nas primeiras páginas da Política de Aristóteles, em que se lê:

\begin{abstract}
O homem, mais do que uma abelha ou um animal gregário, é um ser vivo político

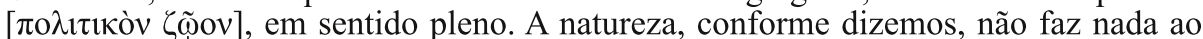
desbarato: só o homem, de entre todos os animais, possui a palavra. Assim, enquanto

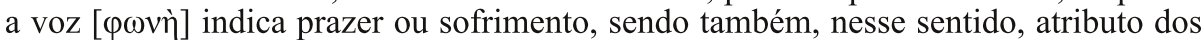
outros animais (cuja natureza também atinge sensações de dor e de prazer e é capaz de as indicar), o discurso, por outro lado, serve para tornar claro o útil e o prejudicial e, por conseguinte, o justo e o injusto. É que, perante os outros animais, o homem tem as suas peculiaridades: só ele sente o bem e o mal, o justo e o injusto, e é a comunidade destes sentimentos que produz a família e a cidade. ${ }^{1}$
\end{abstract}

Pode ser surpreendente perceber que a própria instituição da política depende de certa divisão da voz, de uma divisão dentro dela, sua partição. Pois, para compreender a política, deve-se discernir a mera voz de um lado e a fala, a voz inteligível, de outro. Há uma grande divisão entre phoné e lógos da qual tudo parece depender, apesar de o próprio lógos ainda estar envolvido pela voz, sendo phoné semantiké, a voz significativa, que relega a mera voz à préhistória. Há uma divisão crucial entre a palavra e a voz, um novo avatar de nossa divisão inicial entre o significante e a voz, com consequências políticas imediatas e dramáticas. ${ }^{2}$

Segundo Aristóteles, a mera voz é aquilo que animais e homens têm em comum, a parte animal do homem. Ela pode indicar apenas prazer e dor, experiências partilhadas tanto pelas feras quanto pelos humanos. Mas a fala, o lógos, não apenas indica, ela expressa ou, melhor ainda, evidencia: evidencia o vantajoso (conveniente) e o nocivo e, consequentemente, o justo e o injusto, o bom e o mau. Se alguém sofre um golpe, pode muito bem gritar, ou seja, emitir uma voz que dê vazão à dor, algo que um cavalo ou cão também faria. Entretanto, tão logo uma pessoa diga "fui ofendido" (prejudicado, maltratado), imediatamente a fala introduz uma medida do certo e do errado. Mais do que extravasar sensações, ela introduz um padrão de julgamento.

O que está em jogo aqui é a oposição entre duas formas de vida: zoé e biós. Zoé é a vida nua, a mera vida, a vida reduzida à animalidade; biós é a vida em comunidade, na pólis, a vida política.

O nexo entre vida nua e política é o mesmo que a definição metafísica do homem como "vivente que possui a linguagem" busca na articulação entre phoné e lógos [...].

\footnotetext{
* Originalmente publicado em Mladen Dolar, "The Politics of the Voice", in A Voice and Nothing More, Cambridge, MIT Press, 2006, cap. 5. pp. 104-124. Trad. Fábio Roberto Lucas, doutorando em Teoria Literária e Literatura Comparada pela USP. Pesquisador CNPq.
} 
A pergunta: "de que modo o vivente possui a linguagem?" corresponde exatamente àquela outra: "de que modo a vida nua habita a pólis?" O vivente possui o lógos tolhendo e conservando nele a própria voz, assim como ele habita a pólis deixando excluir dela a própria vida nua. ${ }^{3}$

Essa densa passagem de Agamben aponta exatamente para a junção crucial: a analogia, que é mais que uma analogia, entre a articulação phoné-lógos e a articulação zoé-biós. A voz é como a vida nua, algo supostamente exterior à política, enquanto o lógos é a contraparte da pólis, da vida social regulada pelas leis e pelo bem comum. Entretanto, a questão mais importante - a questão do livro de Agamben - está, é claro, no fato de não existir essa exterioridade simples: a estrutura básica, a topologia da política estabelece, segundo o filósofo italiano, uma "exclusão inclusiva" da vida nua. Essa exclusão coloca a zoé em um lugar central e paradoxal; a exceção recai na interioridade ("Chamemos relação de exceção a esta forma extrema de relação que inclui alguma coisa unicamente através de sua exclusão"). ${ }^{4}$ Uma vez mais, isso coloca a voz em uma posição peculiar e paradoxal: a topologia da extimidade, ${ }^{5}$ a inclusão/exclusão simultânea, que retém o excluído em seu núcleo. Pois o que apresenta problema não é que a zoé seja simplesmente o pré-social, a animalidade, o lado de fora da sociedade, mas que ela persista, em sua própria exclusão/inclusão, no coração do social assim como a voz não seria meramente um elemento externo à fala, mas persistiria em seu núcleo, tornando-a possível e assombrando-a constantemente com a impossibilidade de simbolizá-la. Ademais, a voz não é o resíduo de um estado pré-cultural anterior, ou de uma fusão primordial e bem-aventurada, quando ainda não havíamos sido amaldiçoados pela linguagem e suas calamidades; pelo contrário, ela é produto do próprio lógos, sustenta-o e atormenta-o ao mesmo tempo.

\section{Viva voce}

Se a voz é excluída e, desse modo, incluída na própria constituição da política e de seu lógos subjacente, então essa topologia tem algumas consequências práticas e empiricamente observáveis. Podemos notar como a voz - em sua função de exterior interno do lógos, como pré-lógos ou extra-lógos aparente - é necessária e convocada em certas situações sociais cruciais e bem definidas. Precisaríamos de uma análise e de uma fenomenologia mais detalhada dessas situações, mas temos alguns exemplos tomados dos mais diferentes níveis. Todos eles dizem respeito àquilo que Althusser chamava de Aparelhos Ideológicos do Estado Igreja, tribunal, universidade, eleições - e todos circunscrevem uma determinada área intensamente codificada e ritualizada dentro deles, pontos estratégicos onde seu caráter ritual se manifesta e se realiza [is performed], bem como seu impacto simbólico é encenado.

A voz está intimamente ligada com a dimensão sagrada e ritualística de situações sociais intrincadamente estruturadas, onde seu uso torna possível realizar [perform] certo ato. Não se pode cumprir [perform] um ritual religioso sem recorrer à voz nesse sentido: deve-se, por exemplo, enunciar orações e fórmulas sagradas labialiter, viva voce, de modo a assumi-las, torná-las efetivas, ainda que todas elas estejam escritas em textos sagrados e todas as pessoas (supostamente) as conheçam de cor. Tais palavras, cuidadosamente guardadas no papel ou na 
memória, podem adquirir força performativa apenas se forem delegadas à voz, e seria como se essa, no fim das contas, as dotasse de sacralidade e garantisse sua eficácia ritual, apesar de ou, melhor, em razão de - seu emprego não adicionar nada ao conteúdo enunciado. Parece-nos que esse emprego da voz ecoa uma voz supostamente arcaica, a voz não amarrada ao lógos, e relembra o uso do shofar nos rituais da religião judaica, uso que, como observado, ${ }^{6}$ Lacan propôs como modelo para o objeto voz. Todas as três grandes "religiões do Livro" dependem da Sagrada Escritura. Nela, a verdade se revela, mas o texto religioso - a letra santa - só se torna efetivo se e quando assumido à viva voz. Ele funciona como um liame social, como ligação da comunidade dos crentes, apenas se e quando uma voz pronuncia aquilo que foi escrito no momento original de fundação, armazenado pela tradição e, além disso, guardado na memória dos fiéis.

Exemplos seculares seguem o mesmo padrão: processos judiciais têm regras estritas sobre quais de suas partes e depoimentos devem ser feitos pela voz. Um guia para jurados nas cortes do Estado da França diz:

\begin{abstract}
A oralidade dos debates é a regra fundamental do tribunal [cour d'assises]. Essa regra determina que a corte possa formar sua convicção baseando-se apenas nos elementos contraditória e oralmente debatidos dentro dela. Essa é a razão pela qual os jurados e membros da corte não podem consultar os arquivos [dossiers] durante as sessões [...]. É pelo mesmo motivo que ninguém pode ler o depoimento de uma testemunha antes que ele ou ela tenha testemunhado: o arquivo é sempre secundário. ${ }^{7}$
\end{abstract}

O fato de essa ser uma prescrição francesa tem significado. A mesma regra geralmente é aplicada em todos os lugares (por exemplo, no código civil alemão: "as partes debatem oralmente [mündlich] a questão legal diante de uma corte competente" ${ }^{8}$ ), mas seu local de nascimento é a Revolução Francesa. O princípio da oralidade - o uso da "viva voz" - e o princípio da natureza pública dos processos judiciais foram os dois fundamentos mais importantes defendidos pelo iluminismo contra os muitos modos de corrupção da prática legal no ancien régime. Ambos foram implementados por decretos da Revolução, tal como a Lei de 16-29 de setembro de 1791: "O interrogatório da testemunha deve ser sempre realizado à viva voz [de vive voix], sem que os testemunhos sejam escritos", 9 exigência essa que foi formalizada pelo Código Napoleônico (1806). O rebaixamento do registro escrito à condição secundária (e até o ponto de sua proibição) era parte da democratização dos processos judiciais: o papel principal era atribuído ao júri e, por princípio, os jurados podiam ser qualquer pessoa (sujeita a certos critérios). A dificuldade estava, contudo, no fato de a maioria dos jurados potenciais serem iletrados. A viva voz era o instrumento pelo qual o sistema legal poderia ser retirado das mãos dos especialistas, com sua terminologia incompreensível e uma multidão de regulamentos anacrônicos. ${ }^{10}$ Ela era o caminho para a democratização da justiça e foi sustentada por outro elemento da "ficção política", qual seja, a afirmação de que a democracia seria uma relação imediata, ou melhor, uma relação da voz: a democracia ideal seria aquela em que todos poderiam ouvir a voz de todos (daí Genebra ser um caso modelo para Rousseau). Entretanto, a proibição da escrita foi uma excentricidade revolucionária, logo substituída pela demanda de que toda palavra legalmente relevante - enunciada à viva voz fosse registrada por escrito. A presença viva da voz deveria ser fixada por um protocolo escrito, o único que poderia funcionar como ato legal. Ainda assim, a palavra escrita não tem poder algum caso não seja precedida e fundada pela viva voz. A autoridade do escrito depende 
de sua condição de cópia fiel da voz. O segundo ato, no sentido de documento legal, deve seguir o primeiro, o ato da voz, e a hierarquia entre os dois é uma ficção judiciária fundamental.

Há, certamente, muitas exceções a essa regra, mas a presença viva da voz é o elemento que define a natureza ritual dos processos judiciais. Os especialistas devem ler em voz alta suas declarações mais técnicas e apenas essa voz transforma sua condição de meros enunciados constativos em enunciados performativos. O mesmo enunciado [statement] adquire o valor de um performativo quando lido em voz alta diante do tribunal, sendo a "letra morta" de um constativo enquanto permanece apenas escrito nos arquivos. Trata-se de um fator do qual nem mesmo o presidente dos Estados Unidos consegue se livrar. Não bastando um depoimento escrito, ele também precisa vir à frente e testemunhar. Uma vez mais, está disponível o texto, a norma escrita com base na qual a corte deve decidir. Contudo, para que a lei se efetive, para que ela seja decretada [enacted], é necessário recorrer à voz, à oralidade. $\mathrm{O}$ tribunal precisa decidir se o caso em questão deve ser subsumido sob a lei e dizer como a letra do texto legal nele se aplica, a corte precisa determinar a verdade da questão e relacioná-la ao direito, e isso só pode ser feito pela voz, viva voce (podemos observar, de passagem, a ligação entre a voz e o estabelecimento da verdade: há um ponto em que a verdade tem de ser vocal, em que a verdade escrita, mesmo que seja literalmente a mesma, não basta). ${ }^{11}$

Se a viva voz é essencial para a justiça como implementação das leis, ela também desempenha um papel central na legislatura. Afinal, "parlamento" deriva de parlare e é um lugar reservado para a fala. Mas aqui a situação é inversa com relação àquela observada no âmbito da justiça: lá a viva voz era necessária à implementação da letra da lei, aqui é o debate à viva voz, a discussão oral com a possibilidade da objeção, que tem lugar na produção do texto legal. $\mathrm{O}$ direito não é o pressuposto, mas o produto do ritual da voz; ele não pode ser aprovado, ao menos em princípio, sem passar pela vocalidade. As duas situações, em sua simetria invertida, sustentam-se mutuamente e formam as duas metades de uma mesma entidade ficcional.

Se essa breve avaliação saltar do universo jurídico ao universitário, será possível observar que, na academia anglo-americana, existe uma instituição chamada viva voce, ou apenas viva: a defesa de uma dissertação ou tese de doutorado deve ser feita "à viva voz". Na maioria das universidades de hoje, todas as provas e exames são realizadas por escrito, de modo que, teoricamente, seria possível viver todo o processo acadêmico e obter um diploma sem jamais abrir a boca. Mas apenas até o dia do "viva": nesse momento, ao passar pelo principal rito de iniciação, a pessoa tem de "dar voz", ou seja, não apenas demonstrar conhecimento, mas desempenhá-lo [perform]. O corpus do saber do candidato está escrito na dissertação, texto que - em uma suposição otimista - foi lido cuidadosamente por todos os membros da banca examinadora. Mas isso não basta, o conhecimento precisa ser declarado [enacted] pela voz e apenas desse modo se efetiva. A experiência mais comum demonstra que essas ocasiões tediosas são, na verdade, uma mera questão de exibição vocal; o suposto trabalho de questionamento e exame do saber do candidato tem pouca relação com o conhecimento em si, e adquire uma dimensão inteiramente ritual e vocal (suprida por conflitos narcísicos e políticas departamentais sob o lema da promoção da ciência pura).

Entretanto, se o "viva" apresenta um extremo do sistema educacional, o seu ritual de saída, por outro lado, a voz é onipresente desde o começo do processo de ensino, ao ponto de 
se manter imperceptível. O mecanismo mínimo da escola (esse Aparato Ideológico do Estado dominante, segundo Althusser) depende da voz do professor. Ela define seu caráter ritual e funciona de modo algo análogo à justiça. Pela voz, o professor se torna o transmissor do saber: ainda que este esteja inteiramente armazenado em livros, só se torna efetivo quando delegado à voz. Tudo pode estar escrito em textos didáticos, mas isso nunca será suficiente, até que o professor os assuma com sua voz e os declare [enacts], mesmo que seja simplesmente lendo em voz alta o que já está escrito. Todo o conhecimento está acessível a todos no livro didático, mas a escola como instituição funciona apenas por causa da voz. Se, no dia do "viva", o estudante precisa "dar voz" de modo a se qualificar para o saber, desde o começo da vida escolar, o saber precisa ser encenado pela voz do professor.

O último exemplo é um pouco diferente e menos evidente: as eleições, em muitas línguas, retiveram uma conexão com a voz - dar a própria voz ao candidato, contar as vozes. Em inglês, o vínculo é fraco - contam-se as cédulas [ballots] - mas ele ainda é claro em alemão: für jemanden stimmen, seine Stimme abgeben, Abstimmung, Stimmabgabe; em francês: compter les voix, donner sa voix; em sueco: att rösta på; em línguas eslavas: glasovanje, glasanje; e outras. Esse caso ainda seria uma metáfora? Como a voz enseja tantas metáforas com limites indeterminados? Sua origem histórica é a votação pela voz, ${ }^{12}$ ou seja, pela aclamação. Bispos católicos, por exemplo, foram eleitos assim durante muito tempo; de modo mais geral, um elemento de aclamação faz parte de todo ritual de coroação monárquica. Reis - livre-nos Deus - nunca foram eleitos; contudo, o povo tinha de "dar sua voz" quando o regente assumia seu cargo. ${ }^{13}$ A coroação - o empossamento de um monarca - não poderia ser propriamente cumprida sem a aclamação formal, que pressupunha certa compreensão do adágio vox populi, vox Dei. Por meio de uma ligação paradoxal, a vontade divina, manifestando-se na escolha do rei, só podia ser implementada expressando-se igualmente pela voz do povo, que não podia opinar. ${ }^{14}$ A população não tinha poder de decisão, possuía voz apenas para confirmar a vontade de Deus. A voz divina, por sua vez, podia se expressar tão somente pela voz do povo. Esta era convocada e só podia responder na convocação. Ainda que a origem do provérbio vox populi, vox Dei seja elusiva, é possível rastreá-la, pelo menos, desde a coroação do "monarca de todos os monarcas", Carlos Magno. A primeira menção ao adágio é de uma carta de Alcuíno para o rei, em 798 d.C. Sua coroação, em 800 d.C., passou por grandes problemas relativos ao seu ritual. Contra o costume anterior, decidiu-se que a coroação precederia a aclamação, e não o contrário, inversão essa que se tornou modelo para o futuro.

As eleições, por sua vez, mantiveram algo desse uso ritual da voz. Em nosso mundo complexo e tecnicamente sofisticado, ainda é necessário dar a própria voz, cumprir [perform] ritualmente, por assim dizer, o mito da sociedade organizada e unida pela voz, onde o povo ainda é chamado para dar sua voz em favor do regente. A fantasia aqui implicada é a da Gemeinschaft na qual todos os membros poderiam ouvir uns aos outros, na qual o vínculo social fundamental seria uma ligação vocal. Porém, a voz eleitoral tem de ser silenciosa (silenciada?): ela deve ser dada por escrito (marcando um " $\mathrm{x}$ " ou círculo) e realizada [performed] em uma pequena cabine, um cubículo, uma cela em total isolamento (em francês, esse espaço, não por acaso, é chamado de l'isoloir) e silêncio. Ademais, o voto deve ser oferecido um por um, de modo que a explosão coletiva da voz aclamatória seja fragmentada, 
cortada pela raiz e aparentemente privada de suas qualidades essenciais e de seu efeito espetaculoso. Pois ela é então medida e contada, torna-se uma voz submetida à aritmética, confiada ao signo escrito, à voz muda carente de toda sonoridade. Ainda assim, não importa o quanto se tente sufocá-la ou desmembrá-la, ela ainda é uma voz. Se a letra da constituição deve ser decretada [enacted], em sociedades democráticas, ela ainda deve sê-lo pela voz.

\section{A antipolítica da voz}

Essas reaparições da voz em meio à vida comum, cujos princípios estariam baseados na "letra da lei", essas ocorrências em momentos rituais ou quase sagrados apresentam evidências altamente reveladoras e sintomáticas de que a voz é chamada a desempenhar [perform] uma função social crucial. Elas apontam para a necessidade do surgimento da voz em certos ritos de uma sociedade exaustivamente governada e organizada por leis, regras e prescrições escritas é a ficção da acessibilidade universal da letra e de sua natureza imutável que torna a lei possível, em oposição ao caráter fluido das vozes. Quando é requerida nessas ocasiões, a voz se apresenta propriamente circunscrita, domesticada, pacificada. Ainda assim, ela é absolutamente necessária para complementar a letra, completá-la, concluí-la. A voz é como a metade perdida da lei, aquela que torna possível sua promulgação [enactement], assegurando ritualmente a autoridade da escrita [letter]. ${ }^{15}$ Esse é o ponto em que o uso ritual da voz difere de sua ligação com o supereu: o que está em jogo no rito é a codificação da voz e sua apresentação pública, seu emprego como suporte da performatividade social, como selo da comunidade e reconhecimento de eficácia simbólica. Trata-se da voz como prática da letra. Com o supereu, o principal é escapar da publicidade, manter seu código escondido - e se essa voz faz uma aparição pública, é para produzir um efeito do obsceno.

Contudo, esse uso ritual não é a única narrativa sobre a voz - ou não constitui toda a sua história -, longe disso. Todos esses casos resumidamente apresentados como exemplos repousam sobre uma estrutura de divisão do trabalho, por assim dizer: há uma coexistência entre a letra e a voz, é bem evidente onde e quando a voz deve intervir para decretar [enact] a letra. As duas funções estão claramente delimitadas e circunscritas, e a ação da voz é convocada em lugares e momentos específicos e bem definidos. Essa divisão dá a impressão de convivência pacífica, complementaridade, tal como se a letra encontrasse no uso da voz a metade perdida que estava procurando. A voz é então empregada apenas nos instantes e locais alocados para ela, e tudo depende da conservação do limite, ainda que este possa estar borrado ou problemático. A divisão do trabalho entre a letra e a voz pode certamente adquirir muitas formas perversas, mas, ela é, ao mesmo tempo e apesar disso, um remédio, uma ferramenta que limita os abusos do poder e se opõe aos seus efeitos nefastos, ainda que seu valor e sua eficácia devam ser cuidadosamente avaliados em cada caso.

Em claro contraste com essa articulação entre a voz e a letra, haveria outro tipo de voz, com uso e função muito diferentes, que teria o efeito não de decretar [enacting], mas de questionar a própria letra e sua autoridade. Com efeito, trata-se da (apropriadamente chamada) voz autoritária, da voz como autoritária, a voz como fonte de autoridade contra a letra, ou ainda, a voz não mais como suplemento, mas como suplantação da letra. É muito significativo que todos os fenômenos de totalitarismo tendam a recorrer presunçosamente à voz, fazendo 
com que um quid pro quo a coloque no lugar da autoridade da letra ou questione sua validade. Surge então uma voz aparentemente ilimitada e solta, ou seja, não mais presa à letra; uma voz que é a fonte e o móvel imediato da violência.

Para fornecer um exemplo leve e divertido de algo efetivamente repulsivo, podemos pensar na performance de Chaplin em $O$ grande ditador. De fato, o uso estrutural da voz no "totalitarismo" nunca foi apresentado de modo tão convincente. Muitos de seus elementos podem ser observados. ${ }^{16}$

1. O que ouvimos no famoso discurso de abertura de Hynkel, o ditador da Tomânia, é uma língua inexistente, com todos os trejeitos do alemão (alguns termos caricatos e identificáveis da língua alemã estão misturados na fala). Não se compreende uma só palavra (ou literalmente apenas um ou outro vocábulo aqui e ali, por exemplo, chucrute); a voz e seu teatro são isolados como característica essencial do ditador, da voz que excede o significado. $\mathrm{O}$ discurso como um todo não é senão uma encenação e uma coreografia da voz. ${ }^{17}$

2. Ao mesmo tempo, percebe-se um tradutor inglês invisível interpretando a fala do ditador, ou seja, fornecendo significado à voz sem sentido do ditador, por meio de um tipo de tradução simultânea. O mecanismo é formidável e impressionante, e parece ser manifestamente ubíquo: o antropólogo Junzo Kawada estudou o papel (político) da voz em diversas sociedades e nos afirma, por exemplo, que, na tribo Mosi, em Burkina Faso, o chefe (rei) sempre fala com uma voz baixa e incompreensível, necessitando de um intérprete que explique ao povo aquilo que ele realmente disse. ${ }^{18}$ Porém, é essencial que o líder esteja lá como fonte da voz, ele precisa emitir a voz, a voz pura e sem sentido, para que, na sequência, seu vizir - ou, por assim dizer, seu segundo em comando - tome conta do significado. Esse dispositivo parece ter funcionado em muitas sociedades - Salazar (1995) analisou sua operação na França do século XVII, uma sociedade largamente governada pelo "culto da voz", como indica o título de seu livro. ${ }^{19}$ Também podemos discerni-la em um modo completamente diferente, como observado, ${ }^{20}$ na "cena originária" bíblica, em que Moisés teve de interpretar a voz de Deus ouvida no monte Sinai para o povo que conseguia escutar apenas trovões e trombetas, em uma clara divisão entre a voz e a lei. O mesmo mecanismo agora é encenado [enacted] de modo caricato: o mestre é a fonte das vozes engraçadas, lado a lado com o intérprete invisível encarregado do seu significado.

3. Entretanto, o grande atrativo dessa cena está no fato de que evidentemente o intérprete não está fazendo uma tradução precisa do discurso de Hynkel, mas, sim, transformando-o em algo "politicamente correto", apropriado aos ouvidos dos leigos. É também muito claro que, para os iniciados, o ditador está dizendo aquilo que só pode ser confiado à voz e, portanto, não comporta tradução. Podemos imaginar que Hynkel promete aliviá-los da aplicação estrita da lei e lhes concede uma "licença para matar"; há uma promessa implícita de pilhagens, saques, espólios, orgias, uma promessa de suspensão da lei - que não pode ser publicamente colocada em palavras - enquanto o intérprete apresenta sua tradução aos ouvidos do grande Outro, do registro histórico, tentando consequentemente minimizá-la, provê-la de um esforço racional e vão que a coloque em boa perspectiva. Desse modo, o intérprete não precisa traduzir as vozes engraçadas para o público, que compreende tudo muito bem; ele tem de agir como um mediador para o Outro, que é diferente da audiência dos iniciados. O paradoxo da cena está no fato de termos duas versões, o discurso do ditador e sua 
tradução, sendo que não entendemos a primeira, mas, ainda assim, sabemos que a segunda é falsa. Mais do que isso, sabemos também muito bem o que está acontecendo, pois a própria discrepância entre as duas versões fornece a pista exata: é no espelhamento entre o discurso e sua tradução que "o objeto ditador" aparece. Percebamos que todo o processo é colocado sob o signo da duplicidade, de modo que precisamos nos manter amplamente atentos. Afinal, estamos lidando com uma questão de dissimulação [“double-crossing”].

4. O discurso inicial - feito pelo ditador - é igualmente duplicado pelo discurso final, feito pelo barbeiro judeu disfarçado de Hynkel. Esse barbeiro é o duplo perfeito do ditador e, sendo confundido com ele, precisa se endereçar às massas nesse papel. $\mathrm{O}$ dublê então fala exatamente o oposto do início e apresenta palavras fortes cheias de humanismo, que fazem um apelo à humanidade e à fraternidade. Entretanto, em uma ironia final, a reação da audiência parece ser a mesma: o entusiasmo é o mesmo, apesar de o conteúdo comunicado ser precisamente o inverso do primeiro. Isso é intrigante, dado que as massas não sabem que aquele não é o verdadeiro Hynkel e sim seu duplo judeu. Devemos, com isso, entender que o povo é infinitamente ingênuo e suscetível a qualquer manipulação? Outro fator importante: a cena final é musicada por um trecho de Lohengrin, um gesto que, sobretudo, só pode reforçar essa ambivalência final. Poderia a cena derradeira obliterar ou desfazer retroativamente aufheben - os efeitos da cena inicial, da qual a última é um remake? Ou a voz ressoa efetivamente além da alegada mensagem humanista, irredutível ao seu conteúdo, apontando para outra coisa de modo ameaçador?

O uso totalitário da voz não é de nenhum modo como as instâncias da divisão do trabalho. Não devemos interpretá-la como uma invocação do sagrado e do ritual, ${ }^{21}$ ou melhor, é justamente por não ser tal dimensão sacra e ritualística que ela tenta fingir sê-la ainda mais, imitá-la, simulá-la, macaquear o rito tão exata e espetacularmente quanto possível. A voz, embora ainda esteja no núcleo, tem uma função muito diferente aqui: o Führer pode muito bem ser o chanceler do Terceiro Reich, o comandante-em-chefe do exército, além de ocupar muitas outras funções políticas. Entretanto, ele não é Führer em função dos papéis dos quais eventualmente se encarregou, tampouco pelo resultado das eleições ou por causa de suas habilidades. É sua relação com a voz que o faz ser o Führer e o vínculo que o liga com os súditos [subjects] é decretado [enacted] como um vínculo vocal; sua contraparte está na resposta dada pela aclamação das massas, uma característica essencial desse discurso. É a voz que faz a lei - "Führerworte haben Gesetzkraft", como Eichmann dirá em Jerusalém; sustentadas pela mera voz, suas palavras fazem a lei, a voz aqui se transforma imediatamente na lei, ou seja, ela a suspende. Era isso que Carl Schmitt proclamava em 1935: "a vontade e o plano do Führer" se manifestam em orientações [Leitsätze] orais, que são "de modo imediato e mais intenso lei positiva". 22 Schmitt era um grande jurista e ele não poderia ter sido mais explícito.

Na pessoa do Führer, zoé e biós coincidem..$^{23}$ Ele representa a unidade do Volk e suas aspirações, suas ambições e propósitos biopolíticos (vale lembrar que a ideia de "biopolítica" em Foucault indicava precisamente a aniquilação da distinção entre zoé e biós), ou seja, nos termos de nossa pesquisa, ele está também entre a voz e o lógos. O biopolítico engole o sagrado, a voz devora a letra, a divisão colapsa e o colapso dessa divisão necessariamente faz emergir a "vida nua" no outro lado: a vida que qualquer um pode matar impunemente e que, 
contudo, não pode ser sacrificada, ou seja, submetida à economia do sacrifício, do dom, da penitência e da expiação, em gesto de intercâmbio com o (divino) Outro. Essa é a vida dos judeus, homines sacri por excelência de nosso tempo. ${ }^{24}$

O uso da voz no stalinismo (geralmente considerado outra parte dessa entidade espúria chamada "totalitarismo" $)^{25}$ apresenta uma estrutura distinta. É imediatamente óbvio que os mandatários stalinistas - a começar pelo próprio Stálin - nunca foram bons oradores em público. A voz desse tipo de governante é o oposto exato daquela do Führer e sua eficácia espetaculosa. Quando faz um discurso público, o político stalinista lê com uma voz monótona, sem a entonação e os efeitos retóricos apropriados, como se ele mesmo não compreendesse o que está dizendo. Os congressos do partido foram sempre encenados como leituras monótonas de uma sequência interminável de falas infinitas, ao longo da qual a história supostamente acontece, ainda que fosse uma história produtora de efeitos irresistivelmente soporíferos, uma história definitivamente desprovida de qualquer drama. Era certo que esses discursos seriam publicados nas páginas densamente cobertas do diário oficial do dia seguinte. Por causa disso, ninguém os escutava (nem os lia impressos no papel depois). Mesmo assim, a performance era essencial e indispensável - não em razão dos delegados presentes no saguão ou do povo hipoteticamente reunido às multidões em torno dos rádios e alto-falantes, mas porque a cena era apresentada em benefício do grande Outro. A apresentação se destinava aos ouvidos do grande Outro da história. Afinal de contas, as medidas stalinistas sempre foram justificadas em termos de realização das grandes leis históricas, com vistas a um futuro que supostamente as validaria.

Se o principal objetivo do mandatário fascista era produzir um Acontecimento aqui e agora, se o fascismo colocava todas as suas forças em mecanismos de fascinação e de espetáculo e se a voz era o meio ideal de produção desses Acontecimentos estabilizadores de uma ligação direta entre o ditador e as massas, o propósito central dos congressos do partido stalinista, por sua vez, era garantir que nada acontecesse e que tudo se passasse conforme o script pré-estabelecido. O roteiro escrito não devia ser disfarçado, muito pelo contrário: o mandatário stalinista não era senão um agente, um funcionário desse roteiro, e o objetivo da leitura monótona era diminuir tanto quanto possível as distrações. A diretriz não era dada pela autoridade da voz, mas pela autoridade da letra - era a letra, portanto, o Acontecimento, com a voz sendo o seu apêndice, um apêndice necessário, dado que os discursos deviam ser lidos em voz alta para serem efetivados; se a publicação não bastava, a voz devia ser reduzida à menor quantidade possível. Que o falante pareça não compreender o que lê é, portanto, um fato estrutural, não um reflexo de suas capacidades intelectuais, embora ocasionalmente seja difícil notar a diferença. Essa situação é quase oposta àquela do fascismo: as palavras do Führer, sustentadas pela presença carismática e imediata da voz, eram imediatamente legisladoras, como observado, ao passo que o mandatário stalinista procura se anular, emudecer a própria voz; afinal, ele é somente o executor do texto, ou seja, um mero instrumento das leis da história, e não o seu criador. Ele não é, portanto, legislador, mas apenas o secretário (ainda que Secretário Geral) que cumpre o curso histórico objetiva e cientificamente estabelecido, o soldado humilde a serviço do Outro. Em outras palavras, ele não age em seu próprio nome, mas em nome do proletariado, progresso, revolução mundial e assim por diante. Com o grande Outro, nada é confiado à voz - está tudo na letra e na sua lei. 
Se os mandatários stalinistas não eram eloquentes, talvez seja significativo que seus opositores tenham sido grandes oradores. Trótski, o arqui-inimigo, foi um discursador brilhante; Tito, embora não fosse excelente, ficava claramente à vontade ao ler e muitas vezes se fiava em digressões espontâneas, feitas na linguagem popular e direcionadas ao "povo humilde", do qual ele mesmo alegava ser parte. Especial é o caso de Castro: dificilmente seria possível considerá-lo um opositor do stalinismo, mas ele segue uma lógica muito diferente em suas aparições públicas, pois apresenta algo como uma síntese impossível de dois elementos opostos: por um lado, geralmente faz seus discursos sem apoio escrito, empregando um estilo explosivo, infinitamente rendido à inspiração do momento, bem como uma retórica barroca e uma confiança obstinada na imediatez da voz; contudo, por outro lado, seus monólogos improvisados duram horas e horas, tornam-se insuportáveis e repetitivos, transformam-se espontaneamente em orações na boca dos líderes do Partido. Desse modo, também acabam adquirindo efeitos soporíficos e realizando seu télos, apesar de o ponto de partida ser o oposto.

Se no stalinismo tudo acontece em nome do Outro da história, no fascismo o próprio Führer assume esse papel do grande Outro. Ele não precisa de leis objetivas; justifica-se ao corporificar a unidade e a aspiração da Nação, sua "vontade de poder" e desejo de espaço vital, bem como de purificação racial. Vida, força, poder, sangue, solo - e a voz na continuação dessa série, a voz no lugar da - em vez da - lei. À luz disso, todo o legado do iluminismo direitos humanos, democracia e assim por diante - poderia surgir apenas como um obstáculo para a agenda biopolítica. O stalinismo, inversamente, era herdeiro do iluminismo e sua catástrofe foi representar sua perversão interna. O terror stalinista era o terror da letra [letter] e da lei em nome do Outro, um terror que, entretanto, tinha no próprio velamento da voz atrás da letra a fonte de sua perversão: a voz stalinista era fraca e monótona, um mero apêndice da letra, contudo, a encenação que a reduzia ao mínimo, sua autoanulação com vistas a apresentar a letra de modo tanto mais objetivo e independente da subjetividade de seu executor - toda essa redução era a fonte do poder stalinista. Quanto menor essa voz se apresentasse, maior seria seu poder, desde o próprio apêndice invisível a qual fora reduzida, uma adição minúscula de voz, mas uma adição que decidia a validade da letra.

\section{A voz e a letra}

Agamben, nas primeiras páginas de Homo sacer, define soberania, na esteira de Carl Schmitt, como um paradoxo:

O soberano está, ao mesmo tempo, dentro e fora do ordenamento jurídico [...]. O soberano, tendo o poder legal de suspender a validade da lei, coloca-se legalmente fora da lei. Isso significa que o paradoxo pode ser formulado também deste modo: "a lei está fora dela mesma", ou então: "eu, o soberano, que estou fora da lei, declaro que não há um fora da lei”, ${ }^{26}$

A soberania está estruturalmente baseada na exceção. Soberano é quem pode suspender a ordem legal e proclamar o estado de emergência, no qual as leis usuais não são mais válidas e a exceção se torna regra. Esse estado emergencial tem uma ligação íntima com a dimensão da "vida nua": com efeito, ele é proclamado quando essa vida enquanto tal está em perigo (diante de catástrofes naturais, guerras, convulsões, 11 de Setembro...), quando alguém é obrigado, em nome dela, a cancelar a validade da vigência normal da lei. Entretanto, é o 
soberano que deve decidir se o perigo enfrentado efetivamente carece dessa medida extremada. Com isso, a própria vigência do direito passa a depender de uma decisão e de um juízo emanando de um ponto fora da lei. No momento mesmo em que se declara estarem em jogo nossas vidas nuas, nossa sobrevivência - nesse sentido, uma questão não política -, estamos lidando com a soberania e com a política em forma pura, com algo que é paradigmaticamente político.

Podemos notar que esse paradoxo coincide largamente com a relação entre a voz e a escrita [letter] que temos examinado. A letra da lei, para adquirir autoridade, tem de se fiar, a certa altura, em uma voz tacitamente pressuposta; o elemento estrutural da voz assegura que a escrita [letter] não é uma "letra morta", pois exerce poder e pode ser decretada [enacted]. Essa estruturação pode tomar a forma de uma divisão do trabalho, de uma "coexistência pacífica", por mais problemática que seja, mas a tensão entre as duas dimensões traz consigo o perigo permanente de algo muito mais sinistro: a voz está estruturalmente na mesma posição da soberania, o que significa que ela pode suspender a validade da lei e dar início a um estado de emergência. A voz se coloca no ponto de exceção que ameaça se tornar a regra, um ponto no qual ela subitamente expõe sua cumplicidade profunda com a vida nua, com a zoé tal como oposta a biós e sobre a qual Aristóteles falava. O emergencial é a emergência da voz na posição de comando, onde sua existência oculta de repente se torna poderosa e devastadora. Ela se encontra precisamente em um local ilocalizável, simultaneamente no interior e no exterior da lei, trazendo, portanto, um risco permanente de estado de emergência.

Uma "política da voz" se abre a partir daí, expondo como a voz é ambivalente e pivotante. A passagem da voz ao lógos é uma passagem imediatamente política, em cujo segundo passo se dá a reemergência dessa voz em meio ao político. Se a relação voz/lógos é análoga à relação voz/letra, podemos então observar que a voz, ou ainda, o objeto voz é novamente colocado na interseção de ambos. Deve existir uma parte da voz que dota a escrita [letter] de autoridade, assim como um ponto no qual a escrita se fia na voz tacitamente pressuposta para sua autoridade. Essa parte inaudível reemerge com um tanto de glamour no uso ritual da voz, emprego no qual essa dimensão vocal escondida aparece com sonoridade positiva, como uma substituta de si mesma, por assim dizer. A topologia paradoxal da voz como essencialmente "entre-os-dois" - e que temos perseguido desde o início - pode agora ser estendida para a relação entre foné e lógos, tanto quanto para a relação entre zoé e biós.

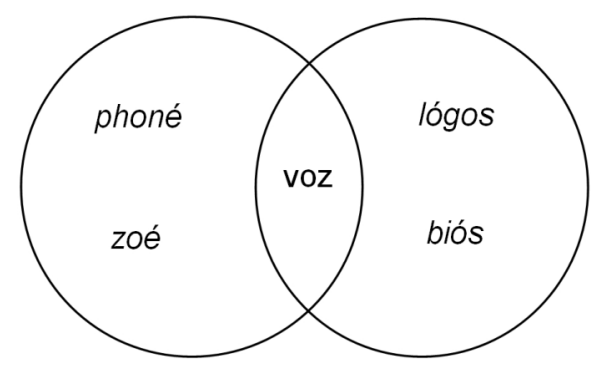

Em todos os casos apresentados, as duas entidades se sobrepõem constituindo um elemento que não pertence a nenhuma delas e que, entretanto, as mantém unidas. Essa localização - na interseção, no vazio - dá à voz um caráter frágil e elusivo, como algo que não pode ser nem reduzido à plena sonoridade de uma presença inequívoca, nem compreendido 
como uma simples ausência. Quando essa voz é tomada como uma coisa positiva e compulsória em si mesma, entramos no domínio em que consequências nefastas rapidamente se seguirão. Na arena política, ela logo se transforma na "Voz do Dono", ${ }^{27}$ que suplanta a lei.

Contudo, no âmbito dessa "política da voz", também devemos seguir a mesma operação do âmbito ético: os usos sociais rituais da voz em sua perversão "autoritária" não cobrem todo seu campo. Nesse ponto, é igualmente necessário desemaranhar, das vozes sonoras e estridentes, a voz não sonora da enunciação pura, a enunciação sem um enunciado [the enunciation without a statement]: uma enunciação cujo enunciado deve ser suprido, um enunciado político em resposta a essa voz - uma resposta que não se constitui ouvindo/obedecendo, nem é construída pelo mero cumprimento dos ritos sociais, mas, sim, pelo comprometimento com uma questão política. Pois a voz está tacitamente implicada não apenas na lei, mas também na ampla textura social, no tecido simbólico sedimentado na tradição e nos costumes, algo que não podemos nunca assumir por mera complacência e submissão, mas exige um ato, uma subjetivação política que pode tomar muitas formas diferentes. A eficácia simbólica depende do excesso da voz que ela inaudivelmente esconde em suas entranhas. Nesse sentido, se comecei evocando Althusser, posso concluir falando brevemente de seu mecanismo de interpelação, que não seria senão outro nome para essa voz, o chamado que sustém as injunções sociais e os mandatos simbólicos. Althusser viu muito claramente que a adesão ao simbólico implicava uma resposta a um chamado e a proveu com um nome excelente. Entretanto, há uma divisão, uma frágil linha de deslocamento, na voz da interpelação: por um lado, o processo de se tornar um sujeito ao se reconhecer como o destinatário do chamado, o que seria aqui uma versão da "Voz do Dono" emitindo prescrições positivas; por outro lado, simultaneamente, a voz que interpela sem impor nenhum conteúdo positivo, algo que provavelmente se perderia obedecendo à voz sonora dos enunciados e ordens; não obstante, esse excesso puro da voz também é compulsório, a diferença estando no fato de ele não nos dizer o que fazer ou oferecer um instrumento de reconhecimento e identificação. Para se transformar em um sujeito, reconhecimento e obediência nunca são o suficiente; em complementação a esses processos e igualmente paralelo a eles, deve-se responder à "mera voz", que é tão somente uma abertura, uma enunciação pura compelindo uma resposta, um ato, um deslocamento das vozes imponentes da dominação. Se, no primeiro caso, a pessoa se transforma em sujeito precisamente ao assumir a forma de um "Eu" autônomo, que renega sua origem heterônoma - vê-se então que dominação ideológica e subjetividade autônoma andam de mãos dadas, como Althusser contundentemente mostrou -, por outro lado, no segundo caso, a pessoa se transforma em sujeito unicamente por sua fidelidade ao "núcleo estrangeiro" da voz, àquilo que não pode ser apropriado pelo eu, ou seja, seguindo justamente a quebra heterônoma a partir da qual a pessoa não mais se reconhece. A interpelação ideológica nunca pode silenciar inteiramente essa outra voz e a distância entre essas duas vozes abre o espaço do político. ${ }^{28}$

Em uma famosa passagem de "Análise terminável e interminável” (1937), Freud fala sobre três profissões impossíveis, nas quais pode se estar certo de resultados insatisfatórios: governo, educação e psicanálise. ${ }^{29} \mathrm{Se}$ as observamos a partir do viés de nossa perspectiva, mostra-se óbvio que todas as três implicam crucialmente a voz em seu núcleo. São profissões da voz e talvez seja o elemento incômodo dessa voz aquilo que, antes de qualquer coisa, as 
torna impossíveis. Vistas de outro ângulo, elas parecem inexequíveis porque todas envolvem transferência e talvez exista um vínculo interno entre as duas: é provável que a voz funcione como o âmago ou o impulsionador da transferência, tanto quanto a voz transferencial ou mesmo a transferência enquanto tal não seja senão outro nome para aquilo que examinamos agora, ou seja, o mecanismo de encenação [enactement] da letra por meio da voz.

Analisamos a primeira profissão, o governo, com alguns dos paradoxos de uma política da voz. Tocamos apenas resumidamente a segunda, a voz na educação, pois um livro com muitos capítulos extensos e escrutínio mais detalhado seria necessário; mas gostaria de encerrar provisoriamente e de modo algo abrupto com uma nota sobre "a voz como pivô da análise". Com efeito, a psicanálise também é uma dessas coisas que só podem ser feitas viva voce, à viva voz, na presença viva do analisando e do analista. A ligação entre eles é vocal (análises por escrito ou mesmo por telefone nunca servirão). Mas a voz de quem? O paciente, o analisando, é quem apresenta suas associações, tudo aquilo que passa por sua mente, na presença do analista. Sendo assim, a princípio, ele é o falante mais importante ou, no limite, o único; o dúbio privilégio da emissão da voz lhe pertence. O analista precisa se manter em silêncio, ao menos no começo ou na maior parte do tempo. Entretanto, aqui, uma curiosa reversão acontece, pois é o analista, com seu próprio silêncio, que corporifica a voz como objeto. É ele ou ela quem se torna a personificação, o corpo da voz, sua encarnação, a voz silenciosa e afônica. Não se trata da "Voz do Dono", nem da voz de comando ou da voz do supereu, mas, sim, de uma voz impossível à qual a pessoa tem de responder. Trata-se de uma voz que não precisa dizer nada, uma voz que não pode ser dita, a voz silenciosa da apelação, um chamado, um apelo a responder, a assumir uma postura como sujeito. A pessoa é convocada a falar, a dizer tudo aquilo que lhe ocorre para, desse modo, interromper o silêncio, silenciar essa voz, silenciar o silêncio; porém, talvez o processo de análise como um todo seja um modo de aprender como assumir essa voz, uma voz na qual o linguístico, o ético e o político juntam forças e convergem naquilo que fora, dentro deles, a dimensão da pura enunciação. Com isso, eles se amarram mutuamente em torno do núcleo pivotante do objeto voz, de seu vazio, em resposta à qual nosso destino como sujeitos linguísticos, éticos e políticos tem de ser despedaçado e reorganizado, atravessado e assumido.

Trad. Fábio Roberto Lucas

\section{Notas de fim}

${ }^{1}$ Aristóteles, Política, trad. Antônio Campelo Amaral e Carlos Carvalho Gomes Lisboa, Vega, 1998, 1253a, pp. 718. N. T.: Esse trecho da Política de Aristóteles recebeu muitas e diferentes traduções. Citamos acima uma que bem expõ̃e as diferenças "entre voz e palavra. Transcrevemos aqui também esta outra, que explicita como tais diferenças constituem o "caráter distintivo" da humanidade em relação à animalidade: "O homem é um animal político mais que todos os outros, abelhas ou animais gregários. Como nós dissemos, com efeito, a natureza nada

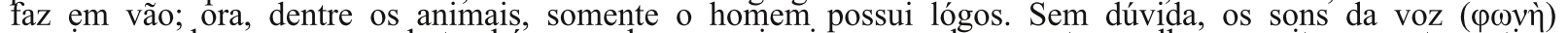
exprimem a dor e o prazer; ela também se acha nos animais em geral: sua natureza lhes permite somente sentir a dor e o.prazer e se manifestar entre si. Mas o lógos é feito para exprimir o útil e o desagradável e, por conseguinte, também o justo e o injusto. Este é, com efeito, o caráter distintivo do homem em face de todos os outros animais: só ele percebe o bem e o mal, o justo e o injusto e os outros valores; ora, é a possessão comum desses valores que faz a família e a cidade". Tradução de Luísa Severo Buarque de Holanda apresentada em "Poetas e filósofos segundo Aristóteles", in Anais de Filosofia Clássica, vol. 2, no. 3, 2008, p. 37.

2 Por uma estranha coincidência, aqueles que talvez sejam os dois livros mais bem conhecidos de filosofia política do final do século XX, duas descobertas da década de 1990, comeccam discutindo essa passagem de Aristóteles. Trata-se de $O$ desentendimento, de Jacques Rancière [edição brasileira: trad. Angela Leite Lopes, São 
Paulo, Ed. 34, 1996, pp. 17-21] e de Homo sacer, de Giorgio Agamben [edição brasileira: Homo sacer I - O poder soberano e a vida nua, trad. Henrique Burigo, Belo Horizonte, Editora UFMG 2002, pp. 9-20]. Os dois títulos foram publicados em suas línguas originais, o francês e o italiano, no ano de 1995 .

${ }^{3}$ Agamben, Homo sacer I, op. cit., p. 15-16.

${ }^{4}$ Idem, p. 26. Para citar alguns dos exemplos do próprio Agamben: o grand renfermement de Foucault funciona como "o encerramento do fora"; ele inclui parte da populaçao ao exclui-la e expô-la a um "tratamento especial" com isso, ela não permanece fora do social, mas no ponto em que os mecanismos sociais se manifestam mais explicitamente. O mecanismo crucial e geral do bando exclui uma pessoa, uma categoria, um grupo de pessoas da lei e, desse modo, define a validade dela ao incluir/excluir seu exterior. "O bandido" se encontra sujeito à lei em sua forma pura.

${ }^{5}$ N. T.: Extimidade (extimité) é um termo da psicanálise lacaniana que Dolar emprega em capítulos anteriores do livro para tentar designar o lugar da voz como uma "exterioridade interna, a intimidade expropriada" (Mladen Dolar, A Voice and Nothing More, Cambridge, MIT Press, 2006, p. 96). Em artigo anterior ("I Shall Be with You on Your Wedding-Night:' Lacan and the Uncanny", Rendering the Real, vol. 58, outono 1991, pp. 5-23), o autor esloveno aborda o conceito de extimidade em Lacan e o compreende a partir de seus vínculos com a noçãao freudiana de unheimlich, o estranho: "Todos os grandes pares conceituais filosóficos - essência/aparência, mente/corpo, sujeito/objeto, espírito/matéria etc. - podem ser vistos como muitas transcrições da divisão entre interioridade e exterioridade. Já a dimensão da extimidade borra esta linha. Ela não aponta nem para o interior nem para o exterior, mas está localizada lá onde a mais íntima interioridade coincide com o exterior e se torna ameaçadora, provocando horror e angústia. A extimidade é simultaneamente o núcleo íntimo e o corpo estrangeiro; em uma palavra, é unheimlich". (trad. Bruno Holmes Chads.)

${ }^{6}$ N. T.: Dolar se refere aqui à seção "Shofar" (pp. 52-56) do capítulo 2 - "A metafísica da voz" -, no qual se retoma um texto de Lacan chamado "A voz de Javé" (in Jacques Lacan, Seminário livro 10 - A angústia, Rio de Janeiro, Zahar, 2005, pp. 266-80). O autor esloveno então analisa o papel do shofar, instrumento de sopro usado em rituais da religião judaica: "Devemos reconhecer, no som do shofar, a voz do Pai, o lamento [cry] de morte do pai primevo da horda primordial, a sobra [leftover] que vem tanto para assombrar quanto para selar a fundação da lei. Ao ouvir essa voz, a comunidade dos crentes estabelece seu pacto [covenant], sua alianca com Deus; eles confirmam sua submissão e obediência à lei. A própria lei, em sua forma pura, antes de comandar algo especificamente, tem seu epítome na voz, a voz que comanda observância total, ainda que ela não tenha sentido em si mesma. A letra da lei adquire sua autoridade a parțir dos resíduos do pai morto, de sua parte não totalmente morta, aquilo que ficou depois de sua morte e que continua a atestar sua presença - sua voz - mas também sua ausência: trata-se do duble de uma presenca impossível, envolvendo um vazio central. Ele funciona como a repeticão ritual de seu sacrifício e como lembrança da origem impossível da lei, acobertando sua falta de origem" (p. 53).

${ }^{7}$ N T.: Trecho citado por M. Poizat, Vox populi, vox dei, Paris, Métailié, 2001, p. 75, e livremente traduzido do inglês a partir da versão apresentada por Dolar em seu livro.

${ }^{8}$ N. T.: Trecho citado por C. Vissmann, “Action Writing: Zur Mündlichkeit im Recht”, in Friedrich Kittler, Thomas Macho e Sigrid Weigel (ed.), Zwischen Rauschen und Offenbarung. Zur Kultur- und Mediengeschichte der Stimme, Berlin, Âkademie Verlag, 2002, p. 142, livremente traduzido do inglês a partir da versão transcrita por Dolar.

${ }^{9}$ Citado por Vissmann, “Action Writing”, op. cit., p. 141, cf. nota 5.

10 Podemos lembrar como ridicularizar a profissão jurídica era um dos pontos mais importantes da comédia iluminista. Tomemos, por exemplo, a cena do tribunal no Fígaro de Beaumarchais.

11 O papel central do imediatismo da voz enfrentou muitos problemas legais com a introdução da gravação sonora e audiovisual nas cortes de justiça (na Alemanha, por exemplo, o vídeo foi permitido em 1998). Na maioria dos países, essas gravações ainda são geralmente consideradas secundárias em relação ao protocolo escrito, supervisionado pelo juiz. Para não dizer nada acerca da exclusão das transmissões dos processos judiciais pelo rádio ou pela TV - entre outras considerações, ela dissiparia a ilusão, a fícção legal da relação imediata com a voz, tomada como locus da justiça.

12 "Vọtar" deriva do latim votum, voveo, que significa anseio ou promessa e não tem nenhuma relação com vox, ou seja, com a voz.

13 Há um grande exemplo dessa questão na ópera. A cena de abertura do Boris Godunóv de Mussorgsky desdobra-se inteiramente em torno do problema da aclamação do rei.

${ }^{14}$ Cf. M. Poizat, Vox populi, vox dei, op. cit., 236 e ss. e passim (ver nota 4), obra que traz uma análise ampla do adágio e de sua ligacão com as eleicỗes. Uma carta de Alcuíno de York afirma: "De acordo com as leis divinas, o povo precisa ser liderado, e não seguido [...]. Não se deve escutar aqueles que dizem vox populi, vox Dei, uma vez que a turbulência da multidão sempre beira a loucura" (p. 238).

${ }^{15}$ Em gesto que seria um contraponto a este, o monarca hegeliano cumpre e decreta a legalidade racional não por meio de sua voz, mas por meio de sua assinatura, um signo escrito sem sentido que torna a lei efetiva. O rei é a excecão constitutiva inscrita dentro do domínio do direito, reduzido ao mero significante, a assinatura ou ato performativo puro, sem significado determinado. Essa era a aposta de Hegel: incluir o ponto de excecão e, desse modo, neutralizá-la, promulgar o império da razão por meio da exceção em seu centro. O propósito dessa estratêgia era reduzir a exceção a uma letra sem sentido, ainda que universalmente acessível e verificável, uma espécie de ponto zero da universalidade, em oposição ao regente totalitáriọ, amarrado à voz. Para a diferença entre os dois, cf. Slavoj Zižek, Tarrying with the Negative, Durham, Duke University Press, 1993, pp. 174-93.

${ }^{16}$ Muito do que se segue devo novamente a Alenka Zupančič (The Shortest Show: Nietzsche's Philosophy of the Two, Cambridge, MIT Press, p. 168-69). Ver também Poizat, Vox populi, vox dei, op. cit., pp. 169-72 (cf. nota 4).

${ }^{17}$ É muito significativo que essa cena seja a primeira na qual o público do cinema pôde efetivamente ouvir a voz de Chaplin, dado que ele tivera muitas duvidas antes de abraçar os "filmes falados".

18 "Nessa sociedade, o rei não se dirige diretamente e em voz alta aos ouvintes que são seus súditos. Sua voz é sempre quieta, grave, baixa. Todas as vezes em que o soberano pausa, um assistente encarregado da repetição 
amplifica e transmite sonoramente as palavras reais ao público. Mas esse amplificador humano não está limitado a reproduzir a fala do líder. Ocasionalmente, ele a completa e modifica, seu estilo ao recitá-la para a audiência". Junzo Kawada, La Voix. Etude d'ethno-linguistique comparative, Paris, Editions de l'EHESS, 1998, p. 12.

19 “O corpo do rei impressiona, domina, desorienta, julga e entorpece não tanto pela luxúria de sua manifestação ou pelas alegorias de seu panegírico, não pelo terror sacro de sua carne intocável e santa narradas pelas, fábulas medievais, mas pelo efeito de sua voz". P.-J. Salazar, Le Culte de la voix au XVIIe siècle, Paris, Editions Champion, 1995, p. 289.

${ }^{20}$ N. T.: Dolạr refere-se aqui, uma vez mais, à seção "Shofar" do capítulo 2, "A metafísica da voz", em que se evoca um episódio do livro do Exodo, o momento da fundação da lei, quando Moisés recebe as tábuas com os mandamentos divinos no monte Sinai. O autor esloveno cita o seguinte trecho da Bíblia: "Vendo os trovões e os relâmpagos, o som da trombeta e a montanha fumegante, todo o povo teve medo e manteve-se à distância. Então disseram a Moisés: 'Fala-nos tu, que nós ouviremos; não nos fale Javé, senão morreremos"” (Exodo 20, 18-19); e nota que shofar, "geralmente traduzido como trombeta, era o elemento da voz em meio ao trovão como ruído natural. Por isso, o shofar [...] está lá como a voz sem conteúdo que se fixa na Lei, como o suporte da Lei, subjacente à sua letra. Há, nesse momento inaugural, uma divisão entre a voz - ouvida pelo povo como uma presença dominante [commanding] - e a Lei, da qual apenas Moisés poderia 'fazer sentido",.

21 Sagrado seria um predicado que se aplicaria apenas no sentido que Agamben apresenta em Homo sacer, ou seja, justamente como uma entidade exterior ao sacro e ao sacrifical, uma abertura ao biopolítico.

22 Citado por Vissmann, “Action Writing”, op. cit., p. 139, cf. nota 5.

23 "Ele se situa, então, em um ponto de coincidência de zoé e biós, corpo biológico e corpo político. Na sua pessoa, eles transitam incessantemente um pelo outro". Agamben, Homo sacer I, op. cit., p. 190.

${ }^{24}$ Este é o ponto em que alguma crítica a Lacan seria apropriada. Nas últimas páginas do Seminário XI, ele afirma: "Há algo de profundamente mascarado na crítica da história que temos vivido. E, presentificando as formas mais monstruosas e pretensamente ultrapassadas de holocausto, o drama do nazismo. Afirmo que nenhum sentido de história, fundado nas premissas hegeliano-marxistas, é capaz de dar conta dessa ressurgênciá, pela qual se verifica que a oferenda, a deuses obscuros, de um objeto de sacrifícios, e algo a que poucos sujeitos podem deixar de sucumbir, numa captura monstruosa". (Lacan, J. O seminário livro XI - Os quatro conceitos fundamentais da psicanálise, trad. M. D. Magno, Rio de Janeiro: Jorge Zahar Editor, 1988, p. 259.

O problema do holocausto não é um problema de sacrifício nem de divindades obscuras.

25 Ver Slavoj Žižek, Did Somebody Say Totalitarianism?, Londres e Nova York: Verso, 2001.

26 Agamben, Homo sacer I, op. cit., p. 22.

27 N. T.: Na seção “His Master'ș Voice, His Master's Ear” (pp. 74-81) do capítulo 3 - "A “físiçca' da voz" -, Dolar narra a história daquele que seria "o logotipo mais bem-sucedido da históría da propaganda", o rótulo da HMV (His Master's Voice), empregado a partir de 1900 no material publicitário de uma fábrica de gramofones e máquinas de escrever, empresa que mais tarde se tornaria uma multinacional britânica do ramo da gravação e distribuição de música. O logotipo exibe um gramofone e, diante dele, um cachorro intrigado por ouvir a vOz de seu falecido primeiro dono, sem que possa, contudo, encontrá-lo dentro do aparelho. $\mathrm{O}$ autor esloveno retoma, a partir dessa imagem, o vínculo etimológico entre obedecer e ouvir (do latim ob-audire, vínculo também encontrado em outras raízes indo-europeias), a passividade da escuta, sobretudo da escuta da voz acusmática, a voz cuja fonte de emissão é indeterminada ou estranha: "O rótulo da HMV exibe um lado da voz, a voz como autoriḍ̛ade, em uma imagem emblemática. Esse poder da voz deriva da dificuldade de mantê-la à dịstância - ela nos atinge a partir do interior, ela se esparrama diretamente dentro de nós, sem proteção. Os ouvidos não têm pálpebras, como. Lacan nunca se cansou de repetir; eles não podem ser fechados, sempre se está exposto, nenhuma distância do som pode ser mantida" (p. 78).

28 Esta afirmacão é apenas uma ideia carente de muito mais elaboracão. Podemos relacioná-la, por exemplo, à oposição feita por Rancière entre polícia e política e à oposição entre identificação usual e subjetivação: "Por subjetịvação vamos entenḍer a produção, por uma série de atos, de uma instância e de uma capacidade de enunciação que não eram identifícáveis num campo de experiência dado, cuja identificação portanto caminha a par com a reconfiguração do campo da experiência". Ranciere, O desentendimento, op. cit., p. 45.

29 Sigmund Freud, Studienausgabe, vol. supl., p. 388. Esse texto importante curiosamente não integra a PFL Edition, de modo que, desta única vez, tenho de me referir a James Stratchei (ed.), The Standard Edition of the Complete Psychological Works of Sigmund Freud, vol. 23, Londres, Hogarth Press, 1953-1973, p. 249. Freud empregou a mesma ideia em seu "Prefácio para a juventude desorientada de August Aichhorn". [Edição standard brasileira das obras psicológicas completas, Rio de Janeiro, Imago, 1992, vol. XIX, p. 341 e ss.] 